\title{
Total Phenolic Content and Associated Phenotypic Traits in a Diverse Collection of Snap Bean Cultivars
}

\author{
Adrienne E. Kleintop \\ Department of Soil and Crop Sciences, Colorado State University, Fort Collins, CO 80523
}

James R. Myers ${ }^{1}$

Department of Horticulture, Oregon State University, Corvallis, OR 97331

Dimas Echeverria and Henry J. Thompson

Department of Horticulture and Landscape Architecture, Colorado State University, Fort Collins, CO 80523

\author{
Mark A. Brick \\ Department of Soil and Crop Sciences, Colorado State University, Fort Collins, CO 80523
}

\begin{abstract}
AdDitional INDEX wORDs. common bean, flavonoids, Folin-Ciocalteu assay
Abstract. Phytochemicals such as phenolic compounds in snap bean (Phaseolus vulgaris) have potential human health benefits. The objectives of this research were to determine the variation in total phenolic content (TPC) measured as gallic acid equivalents (GAEs) - expressed on a fresh weight (FW) basis throughout this study-among a diverse collection of both indeterminate climbing (pole) and determinate (bush) bean cultivars $(n=149)$ using the FolinCiocalteu assay. We also evaluated associations between TPC and phenotypic traits and estimated genotype by environment $(G \times E)$ interactions in a subset of the cultivars. The TPC had greater than a 4-fold difference among cultivars and ranged from 0.29 to $1.31 \mathrm{mg} \cdot \mathrm{g}^{-1} \mathrm{GAE}$ (mean $=0.49 \mathrm{mg} \cdot \mathrm{g}^{-1} \mathrm{GAE}$ ). Cultivars were classified into categories of high ( $\left.\geq 1.00 \mathrm{mg} \cdot \mathrm{g}^{-1} \mathrm{GAE}\right)$, intermediate $\left(>0.64\right.$ to $\left.<1.00 \mathrm{mg} \cdot \mathrm{g}^{-1} \mathrm{GAE}\right)$, and low $\left(<0.55 \mathrm{mg} \cdot \mathrm{g}^{-1} \mathrm{GAE}\right) \mathrm{TPC}$. Eighty-four percent, $10 \%$, and $6 \%$ of the cultivars fell into the low, intermediate, and high categories, respectively. The pole type cultivars had higher TPC $\left(\right.$ mean $\left.=0.86 \mathrm{mg} \cdot \mathrm{g}^{-1} \mathrm{GAE}\right)$ when compared with the bush cultivars $(\mathrm{mean}=$ $\left.0.47 \mathrm{mg} \cdot \mathrm{g}^{-1} \mathrm{GAE}\right)$. Correlations were observed between TPC and both flower and pod pigmentation. $G \times E$ interactions did not occur among pole type cultivars for TPC during 2 years of production, but a significant $G \times E$ interaction was observed among bush cultivars. The results demonstrate a wide diversity in snap bean cultivars for TPC, and the pole beans averaged higher TPC than bush bean cultivars. This information should be useful to identify high TPC snap bean cultivars.
\end{abstract}

Common bean is consumed globally both as a dry bean and also as a vegetable. Two main forms of vegetable beans are consumed, shelled high moisture seeds (shell outs or fresh beans) and snap beans (also referred to as green, garden, or french bean), which are consumed as low fiber and fleshy, stringless, immature pods (Blair et al., 2010; Myers and Baggett, 1999).

Both dry and snap beans have about the same levels of consumption in the United States, but the snap bean market has greater profit potential (Myers and Baggett, 1999). Snap beans are consumed in moderate quantities relative to other vegetable crops, with $3.1 \mathrm{~kg} /$ capita consumed in the United States in 2012 [U.S. Department of Agriculture (USDA), 2014]. Processed snap beans are consumed as a canned or frozen product. Canned snap bean consumption in the United States $(1.4 \mathrm{~kg} /$ capita) has been declining in recent years, and is associated with an increase in frozen $(0.9 \mathrm{~kg} /$ capita $)$ and fresh bean consumption (0.9 kg/capita) (USDA, 2014).

Snap beans bred for processing adhere to strict pod quality requirements including sieve size (pod diameter), pod crosssectional shape (round as opposed to oval), fiber content (low

Received for publication 9 June 2015. Accepted for publication 25 Sept. 2015. Funding for this research was provided by the Bean Coordinated Agricultural Project (USDA-NIFA-2009-85606-05964).

${ }^{1}$ Corresponding author. E-mail: james.myers@oregonstate.edu. and no pod suture strings), and seedcoat color (white or pale green) (Myers and Baggett, 1999). Snap bean cultivars also differ regarding growth habit, where determinate bush cultivars are used for mechanical harvest because they maximize the quantity of mature pods at one harvest date and indeterminate pole beans that are trellised and often hand harvested over a period of time (Myers and Baggett, 1999). Seeds must lack color because anthocyanins from colored seeds can discolor the canned or frozen product and reduce quality (Blair et al., 2010; Myers and Baggett, 1999). Other processing quality traits include pod color, smoothness, straightness, and pod length (Myers and Baggett, 1999). Snap beans bred for fresh market may differ by having higher fiber content and relaxed standards on pod size and cross-sectional shape (oval cross section may be permitted), and in some fresh markets, colored seed may be acceptable (Myers and Baggett, 1999).

Dry bean consumption has been associated with human health benefits such as a reduced risk of diabetes, heart disease, colon cancer, prostate cancer, and mitigation of obesity (Bazzano et al., 2001; Câmara et al., 2013; Thompson et al., 2009). There is less knowledge about the nutritional value and health benefits of snap beans, and to our knowledge, no human health studies similar to those conducted for dry beans have been reported. However, in animal model studies, extracts from green bean pods were shown to have a strong antihyperglycemic effect (Roman-Ramos et al., 1995) and improved collagen 
accumulation in streptozotocin-induced diabetic rats (Pari and Venkateswaran, 2003).

Both dry and snap bean cultivars contain a number of secondary compounds with potential health benefits including vitamin $\mathrm{C}$, carotenoids, tocopherols, and phenolics. The presence of various phytochemicals including phenolics in snap beans may have potentially advantageous health benefits, similar to those of dry bean. Phenolics are a large class of phytochemicals with over 8000 individual compounds, structurally characterized by an aromatic ring with one or more hydroxyl groups (Crozier et al., 2009; Hounsome et al., 2008; Parr and Bolwell, 2000). Phenolic compounds are divided into flavonoids (including subclasses: flavonols, flavones, flavan-3-ols, anthocyanidins, flavanones, isoflavones, and other minor subclasses) and nonflavonoids (including subclasses: phenolic acids, hydroxycinnamates, and stilbenes) (Crozier et al., 2009). Total phenolic content has been shown to be a major contributor to antioxidant activity in legumes (Amarowicz and Pegg, 2008).

Although human health trials are lacking, several groups have characterized snap beans for various individual phenolic compounds. At least 72 compounds including 10 phenolic acids and 59 flavonoids were tentatively identified by Abu-Reidah et al. (2013). The individual compounds that predominate are quercetin and kaempferol as the main flavonol glucosides along with $(+)$ catechin and $(-)$ epicatechin, chlorogenic and protocatechuic acids, as well as procyanidins (Escarpa and Gonzalez, 2000; Mattila and Hellström, 2007). Hertog et al. (1992) found relatively high levels of flavonoids in processed fresh beans, ranging from 20 to $51 \mathrm{mg} \cdot \mathrm{kg}^{-1}$. A 10-fold range in flavonoid concentration was observed in a study of six wax and green bean cultivars and ranged from 19 to $184 \mu \mathrm{g} \cdot \mathrm{g}^{-1} \mathrm{FW}$ for quercetin derivatives and 6 to $15 \mu \mathrm{g}^{\mathrm{g}} \mathrm{g}^{-1}$ for kaempferol derivatives (Hempel and Böhm, 1996).

Many of the individual genes functioning in the biosynthetic pathways for flavonols and anthocyanins and relating to phenolic composition are thought to be involved in controlling seedcoat color, patterning, and flower color (Bassett, 2007; McClean et al., 2002). Potential associations between the seedcoat color genes and genes and transcription factors functioning in the phenylpropanoid biosynthetic pathway were identified in common bean, and many of the seedcoat color genes also mapped to regions of conserved synteny between common bean and soybean (Reinprecht et al., 2013). The genetic control of seedcoat color and patterning and flower color in common bean is complex and involves multiple multiallelic genes and their interactions (Bassett, 2007; McClean et al., 2002). An extensive review of the genetics of seedcoat color and patterning and flower color in common bean was conducted by Bassett (2007). Genes of interest in the present study include: $P$, which controls seedcoat and flower color; $T$, which controls partial coloring in seedcoats and flowers; $C$, which controls various seedcoat patterning; and the closely linked $R$, which expresses a dominant red color (Bassett, 2007). Additional genes that interact with $P$ and each other to modify or intensify the seedcoat color include $R k, G, B$, and $V$, the latter of which was of particular interest to this research because it includes the recessive allele $v$ that confers white flower color and the dominant allele $V$ that confers a purple flower color, and another allele $v^{\text {lae }}$ (hypostatic to $V$ and epistatic to $v$ ) that confers lavender flower color in a $P T$ background (Bassett, 2007). Anthocyanins may also be expressed in other plant tissues, including pods in cultivars with purple pigmentation of flowers.

The Common Bean Coordinated Agricultural Project (Bean CAP) was a multi-institutional, multidisciplinary grant funded by the USDA - Agriculture and Food Research Initiative to assemble panels of dry and snap bean cultivars to assess these panels for agronomic and nutritional traits, and to develop single nucleotide polymorphic markers. The Bean CAP Snap Bean Diversity Panel consists of 149 cultivars and germplasm accessions that represent the diversity among snap beans. The objectives of our research were to: 1) determine the variation in TPC (milligrams GAE per gram FW) in a diverse collection of snap bean cultivars, 2) determine if TPC is associated with phenotypic traits such as growth habit and flower color, and 3 ) estimate genotype by environment effects for a subset of pole and bush cultivars.

\section{Materials and Methods}

Plant material. To evaluate TPC, a diverse collection of 149 snap bean cultivars comprising the Bean CAP Snap Bean Diversity Panel were grown at Oregon State University (OSU) at Corvallis, OR, during the 2010 growing season. The cultivars were planted into three field replicates using a randomized complete block design. Seeds were planted in 76- $\mathrm{cm}$ rows with a within-row spacing averaging $5 \mathrm{~cm}$ in plots of $4 \mathrm{~m}$ in length. For fertility, $168 \mathrm{~kg} \cdot \mathrm{ha}^{-1}$ of $10 \mathrm{~N}-4.4 \mathrm{P}-8.3 \mathrm{~K}$ was banded in the row at planting. Weeds were controlled with application of $0.9 \mathrm{~kg} \cdot \mathrm{ha}^{-1} \mathrm{~S}-$ metolachlor preemergent herbicide (Dual; Syngenta, Basel, Switzerland) supplemented by mechanical cultivation. Twelve western spotted cucumber beetles (Diabrotica undecimpunctata undecimpunctata) were controlled in young seedlings by the application of $1.0 \mathrm{~L} \cdot \mathrm{ha}^{-1}$ carbaryl insecticide (Sevin; Bayer, Research Triangle Park, NC). Plots received $\approx 2.5 \mathrm{~cm}$ of water per week from planting to harvest via solid set overhead sprinklers. Fresh pods of the predominant sieve size (Supplemental Table 1) for each cultivar were handpicked in the field at OSU, brought to the laboratory and immediately frozen at $-20{ }^{\circ} \mathrm{C}$. Harvest maturity was determined by observing seed development and initiating harvest when seeds in the most mature pods had reached a length of $\approx 10 \mathrm{~mm}$. Approximately 10 pods per plot $(50-100 \mathrm{~g})$ were randomly selected from the plants within a plot. Samples were evaluated for phenotypic traits at OSU and then shipped on dry ice to Colorado State University where they were stored at $-80{ }^{\circ} \mathrm{C}$ until TPC analysis.

To determine if $\mathrm{G} \times \mathrm{E}$ effects for TPC occur, a subsample of six pole and half-runner cultivars (Corbette Refugee, Fortex, Kentucky Wonder, McCaslan No. 42, Pole Blue Lake, and Trail of Tears) and six bush cultivars (Banga, Ebro, Goldmine, Impact, OR5630, and Storm) were grown in three field replicates during the 2011 growing season in Corvallis, OR. Pods of the pole and bush cultivars were hand harvested when pods reached harvest maturity as described above. The cultivars used in this portion of the study were chosen for their diversity in TPC based on the 2010 data to maximize genetic variability.

Phenotypic Traits. Phenotypic traits that were evaluated included visual assessments of flower and seed color and the color of fresh and thawed pods, which were evaluated with a colorimeter (Minolta BC-10; Konica Minolta Sensing Americas, Ramsey, NJ) using the Commission Internationale de l'Eclairage (CIE) $\mathrm{L}^{*}, \mathrm{a}^{*}$, and $\mathrm{b}^{*}$ scale (CIE, 2008). The 
$\mathrm{L}^{*}$ scale is a measure of the lightness vs. darkness and ranges from 0 (black) to 100 (white). The $\mathrm{a}^{*}$ vector measures the color scale from green $(-)$ to red $(+)$ and the $\mathrm{b}^{*}$ vector measures from blue (-) to yellow $(+)$ in relative numbers (CIE, 2008). Fresh pods were evaluated immediately after harvesting and the frozen pods were allowed to thaw completely for $\approx 90 \mathrm{~min}$ at ambient temperature $\left(\approx 24^{\circ} \mathrm{C}\right)$ before their color was measured.

Flower color was evaluated visually in field plots and was classified for associated allelic composition at the $V$ locus using the categories: purple (corresponding to $V$ ), lavender $\left(v^{\text {lae }}\right)$, and white $(v)$. Pod color was determined visually on fresh pods at harvest maturity and cultivars were classified into three general categories: purple, green, and yellow (wax). Although a range of colors were seen in the seed of the snap bean panel, we classified seed color into three categories (colored, partially colored, and white) for the purposes of this study. Mature dry seeds used for planting were used to classify seed color, which was further classified by putative genotype in relation to known genes affecting color and patterning, or modifying color intensity or shades. Genotypic determination was based on a combination of observed flower and seedcoat color using Prakken (1934, 1940, 1970, 1972a, 1972b, 1974) and Bassett (2007) to associate genes to observed phenotype.

Folin-Ciocalteu assay. The TPC was evaluated on frozen pod tissue from the 2010 and 2011 crop years. The TPC was analyzed spectrophotometrically using an adapted Folin-Ciocalteu colorimetric method (Singleton and Rossi, 1965 ) and performed in a microplate format. The assay is based on the color reaction of phenolic compounds with FolinCiocalteu phenol reagent that absorbs light at $765 \mathrm{~nm}$. The TPC is a measure of the reducing capacity of a sample through electron transfer reactions, expressed as GAEs. All TPC values are expressed as milligrams GAE per gram FW of tissue. Pod sample extracts were prepared according to the methods by $\mathrm{Xu}$ and Chang (2007). A 20-g sample of each field replicate was ground to a fine powder using a mortar and pestle in liquid nitrogen. The powdered samples were stored at $-80{ }^{\circ} \mathrm{C}$ until analysis. The Folin-Ciocalteu assay used a $0.5-\mathrm{g}$ sample of snap bean pods from each field replicate, placed in a $15-\mathrm{mL}$ centrifuge tube, and assays were replicated three times. To each sample, $5 \mathrm{~mL}$ of a prepared acetone/water/acetic acid $(70: 29.5: 0.5 \mathrm{v} / \mathrm{v} / \mathrm{v})$ extraction solvent was added and the tubes were capped and shaken at room temperature $\left(22 \pm 2{ }^{\circ} \mathrm{C}\right)$ for $2 \mathrm{~h}$ using an orbital shaker. The tubes were then stored at $4{ }^{\circ} \mathrm{C}$ in the dark overnight. The following morning, the tubes were centrifuged at $2000 g_{\mathrm{n}}$ for $10 \mathrm{~min}$, and the supernatants were transferred to new tubes. To conduct the Folin-Ciocalteu assay, a $2.5 \mathrm{mg} \cdot \mathrm{mL}^{-1}$ stock solution of gallic acid was prepared in acetone/water/acetic acid (70:29.5:0.5 v/v/v). The linear working range of gallic acid was found to be $0.005-0.25 \mathrm{mg} \cdot \mathrm{mL}^{-1}$. This stock solution was serially diluted to final concentrations of $0.125,0.063,0.031,0.016$, and $0.008 \mathrm{mg} \cdot \mathrm{mL}^{-1}$ and used to prepare a calibration curve. Dilutions of the sample extracts were made if necessary to fit into the calibration curve. A 96well microplate was prepared and $20 \mu \mathrm{L}$ of each sample extract was added to the well plate to react with $100 \mu \mathrm{L}$ of $1: 10$ diluted Folin-Ciocalteu reagent for $2 \mathrm{~min}$. Next, $80 \mu \mathrm{L}$ of $\mathrm{Na}_{2} \mathrm{CO}_{3}$ $(7.5 \%)$ was added to each sample and then plates were allowed to react in the dark for $2 \mathrm{~h}$ at room temperature $\left(22 \pm 2{ }^{\circ} \mathrm{C}\right)$. The plates were then read at $\lambda=765 \mathrm{~nm}$ using a SpectraMax Plus (Molecular Devices, Sunnyvale, CA) plate reader. Standards were run on each plate and were used to compute the concentration of each sample in milligrams GAE per gram FW using the linear equation $(y=m x+b)$ of the calibration curve.

Statistical analysis. An analysis of variance (ANOVA) was conducted on the 2010 set of samples using the PROC GLM procedure in SAS (version 9.3; SAS Institute, Cary, NC). The Tukey-Kramer multiple comparison method was used to determine significance among entries. An ANOVA was conducted on a subset of bush and pole cultivar subsamples to evaluate $\mathrm{G} \times \mathrm{E}$ from the 2010 and 2011 data using the GLM procedure in SAS. Pearson correlation coefficients were computed to determine associations between mean cultivar TPC and phenotypic traits from the 2010 set of samples. To study the association of flower color with TPC and L*a*b* color scores, data were analyzed by PROC GLM with flower color as the independent variable and the other traits as dependent variables. Least square means were calculated and compared under the null hypothesis that all least square means were equal.

\section{Results}

The results indicate a large range of variation for TPC among the 149 snap bean cultivars (Supplemental Table 1). The mean TPC among cultivars was $0.49 \mathrm{mg} \cdot \mathrm{g}^{-1} \mathrm{GAE}$ and ranged from 0.29 to $1.31 \mathrm{mg} \cdot \mathrm{g}^{-1} \mathrm{GAE}$, accounting for a 4.4 -fold difference in TPC. Cultivars were classified into three categories of: low $\left(<0.55 \mathrm{mg} \cdot \mathrm{g}^{-1} \mathrm{GAE}\right)$, intermediate $(>0.64$ to $\left.<1.00 \mathrm{mg} \cdot \mathrm{g}^{-1} \mathrm{GAE}\right)$, and high TPC $\left(\geq 1.00 \mathrm{mg} \cdot \mathrm{g}^{-1} \mathrm{GAE}\right)$. Among the cultivars, $125(84 \%)$ were classified as low TPC and ranged from 0.29 to $0.54 \mathrm{mg} \cdot \mathrm{g}^{-1} \mathrm{GAE}$ with a mean of $0.41 \mathrm{mg} \cdot \mathrm{g}^{-1} \mathrm{GAE}$. No differences were observed among the low TPC cultivars. Fifteen cultivars $(10 \%)$ were classified as intermediate TPC and ranged from 0.64 to $0.99 \mathrm{mg} \cdot \mathrm{g}^{-1} \mathrm{GAE}$ with a mean of $0.83 \mathrm{mg} \cdot \mathrm{g}^{-1} \mathrm{GAE}$, and nine cultivars $(6 \%)$ were categorized as high TPC with a range of $1.00-1.31 \mathrm{mg} \cdot \mathrm{g}^{-1} \mathrm{GAE}$ and a mean of $1.13 \mathrm{mg} \cdot \mathrm{g}^{-1} \mathrm{GAE}$ (Table 1; Supplemental Table 1).

Among the cultivars evaluated, 10 were pole types or half runners and 139 were bush types. The mean TPC of pole and half-runner cultivars was higher $\left(P \leq 0.05 ; 0.86 \mathrm{mg} \cdot \mathrm{g}^{-1} \mathrm{GAE}\right)$ than bush cultivars $\left(0.47 \mathrm{mg} \cdot \mathrm{g}^{-1} \mathrm{GAE}\right)$. The majority of the pole and half-runner cultivars were in the high and intermediate TPC categories; however, two pole cultivars, Pole Blue Lake and the closely related Pole Blue Lake S7, were in the low TPC category. The bush snap beans exhibited a range of variation for TPC and were distributed in all three categories (Supplemental Table 1).

The snap bean cultivars were classified by pod color, and CIE L*, $a^{*}$, and $b^{*}$ color scores were recorded on both fresh and frozen pods as a quantitative measure of pod pigmentation. The majority of the cultivars evaluated had green pods; however, a limited number of cultivars had purple- or yellow-pigmented pods (Table 1). The purple-pigmented 'Blue Peter Pole' (1.31 $\mathrm{mg} \cdot \mathrm{g}^{-1} \mathrm{GAE}$ ) and 'Royal Burgundy' (1.18 $\mathrm{mg} \cdot \mathrm{g}^{-1} \mathrm{GAE}$ ) were ranked as the first and third highest numerically in TPC (Table 1; Supplemental Table 1). In addition, there were groups of cultivars with green and yellow pigmentation and low TPC, and groups of green- or yellow-pigmented cultivars with intermediate to high TPC (Fig. 1A-C). The yellow-pigmented 'Brittle Wax', 'Bronco', 'Carson', 'Goldmine', 'Goldrush', 'Romano Gold', 'Sonesta', and 'Unidor' were categorized in the low TPC category. However, two yellow-podded cultivars Roc D'or (1.08 $\left.\mathrm{mg} \cdot \mathrm{g}^{-1} \mathrm{GAE}\right)$ and Cherokee (0.99 $\left.\mathrm{mg} \cdot \mathrm{g}^{-1} \mathrm{GAE}\right)$ were in 
Table 1. Snap bean cultivars from the Bean Coordinated Agriculture Project Snap Bean Diversity Panel that contain high, intermediate, or low pod total phenolic content (TPC) and phenotype or genotype for flower, seed, and pod color.

\begin{tabular}{|c|c|c|c|c|c|}
\hline Cultivar & $\begin{array}{c}\text { TPC [GAE } \\
\left.\left(\mathrm{mg} \cdot \mathrm{g}^{-1} \mathrm{FW}\right)\right]^{\mathrm{z}}\end{array}$ & Flower color ${ }^{\mathrm{y}}$ & Seed testa color & Pod color & Putative genotype ${ }^{\mathrm{x}}$ \\
\hline \multicolumn{6}{|c|}{ High $T P C^{x}$} \\
\hline Blue Peter Pole & 1.313 & $V$ & Colored & Purple & $P ? ? ?\left[c^{u} r\right] T J$ \\
\hline Royal Burgundy & 1.182 & $V$ & Colored & Purple & $P ? ? R k\left[c^{u} r\right] T j$ \\
\hline Trail of Tears & 1.159 & $V$ & Colored & Green & $P B ? R k[C r] T$ \\
\hline Landreth's Stringless Green Pod & 1.147 & $v^{\text {lae }}$ & Colored & Green & $P B ? R k[C r] T$ \\
\hline Roc D'or & 1.082 & $v^{\text {lae }}$ & Colored & Yellow & PBGRk[CR]TJ \\
\hline Fortex & 1.008 & $v$ & Colored & Green & PBGRk[Cr]TJ \\
\hline Black Valentine & 0.997 & $V$ & Colored & Green & $P B ? R k[C r] T J$ \\
\hline \multicolumn{6}{|c|}{ Intermediate TPC } \\
\hline Cherokee & 0.988 & $V$ & Colored & Yellow & $\operatorname{Pbgrk}[\mathrm{Cr}] T$ or $P b g R k[C R] T$ \\
\hline Oregon Giant Pole & 0.939 & $V$ & Colored & Green & $P B ? R k\left[c^{r h o} r\right] T$ \\
\hline Magnum & 0.826 & $v$ & Colored & Green & $P B ? R k[C r] T J$ \\
\hline Stringless French Fillet & 0.823 & $v$ & Colored & Green & $P B ? R k\left[c^{m o} R\right] T J$ \\
\hline Corbette Refugee & 0.788 & $V$ & Colored & Green & $P B ? R k\left[c^{m o} R\right] T J$ \\
\hline Provider & 0.772 & $V$ & Colored & Green & Pbgrk[Cr]TJ or PbgRk[CR]TJ \\
\hline Top Crop & 0.727 & $v^{\text {lae }}$ & Colored & Green & $P B ? R k\left[c^{m o} r\right] T J$ \\
\hline Tendercrop & 0.676 & $v$ & Colored & Green & $P B ? R k\left[c^{m o} R\right] T J$ \\
\hline \multicolumn{6}{|c|}{ Low TPC } \\
\hline Banga & 0.544 & $v$ & White & Green & $p ? ? ? ? ? ?$ \\
\hline Bronco & 0.484 & $v$ & White & yellow & p?????? \\
\hline Pole Blue Lake S7 & 0.478 & $v$ & White & Green & p?????? \\
\hline Pole Blue Lake & 0.472 & $v$ & White & Green & p?????? \\
\hline Oregon 5630 & 0.294 & $v$ & White & Green & p?????? \\
\hline
\end{tabular}

${ }^{\mathrm{z}} \mathrm{GAE}=$ gallic acid equivalent; $\mathrm{FW}=$ fresh weight.

${ }^{\text {y}}$ Flower color observed in the field where $V=$ purple, $v^{\text {lae }}=$ lavender, and $v=$ white. 'Brittle Wax' flower color is inferred based on seedcoat color because allele $t$ is epistatic to allele $V$ for flower color.

${ }^{x}$ Putative genotype for seed testa color genes. $P$ - is colored, $p$ is white; $V$ - is black or purple, $v$ and $v^{l a e}$ are brown; $B$ - conditions various shades of brown, $b$ is buff to cream to greenish; $G$ - is greenish yellow factor, $g$ is pale cream to buff; $R k$ is recessive red factor where $r k$ is either red or pink; $[C R]$ complex $C$ and dominant red factor, $C$ produces solid colors, $c^{m o}$ produces mottling, $c^{\text {rho }}$ produces dark flecking on a light background, $c^{u}$ is cartridge buff consisting of purple stippling on a pinkish background; $R$ produces solid red or mottled red depending on the state of $C$; $T$ is partially colored when recessive; $J$ is a dominant after-darkening factor, and ? indicates that a gene is masked by the expression of others and cannot be inferred (Bassett, 2007). The high and intermediate categories are a full list of all cultivars placed in both categories. The low category consists of representative samples and cultivars with notable flower, pod, or seed color. For a full list, see Supplemental Table 1.

the high and intermediate categories, respectively (Table 1; Supplemental Table 1; Fig. 1A-C).

The CIE $\mathrm{a}^{*}$ and $\mathrm{b}^{*}$ scores for fresh pods were highly correlated with TPC; however, the $\mathrm{L}^{*}$ score for fresh pods was not correlated to TPC (Table 2). The association between CIE color scores and TPC was less pronounced with frozen pods, because only $\mathrm{L}^{*}$ was weakly correlated to TPC in frozen pods (Table 2).

When means of cultivars by pod color classification were compared, $V$ and $v^{\text {lae }}$ were not significantly different but were different from $v$ for TPC (Table 3). This is substantiated by the observation that the $V$ and $v^{\text {lae }}$ alleles were only present in the high and intermediate TPC categories; however, all of the cultivars in the low category carried the $v$ allele with the exception of Brittle Wax (Supplemental Table 1). Similarly, $V$ and $v^{\text {lae }}$ were not significantly different from each other, but were significantly different from $v$ for frozen $\mathrm{L}^{*}$ (Table 3$)$. Fresh $\mathrm{b}^{*}$ showed a reverse pattern where $v$ and $v^{\text {lae }}$ were not significantly different, but were significantly higher than $V$. For fresh $\mathrm{L}^{*}, v^{\text {lae }}$ was significantly greater than either $v$ or $V$, which were not significantly different from each other. For fresh $\mathrm{a}^{*}$, $V$ was significantly different from $v$, but $v^{\text {lae }}$ was intermediate and not significantly different from either $V$ or $v$. Differences among flower color classes were not significant for frozen $b^{*}$ (Table 3). 


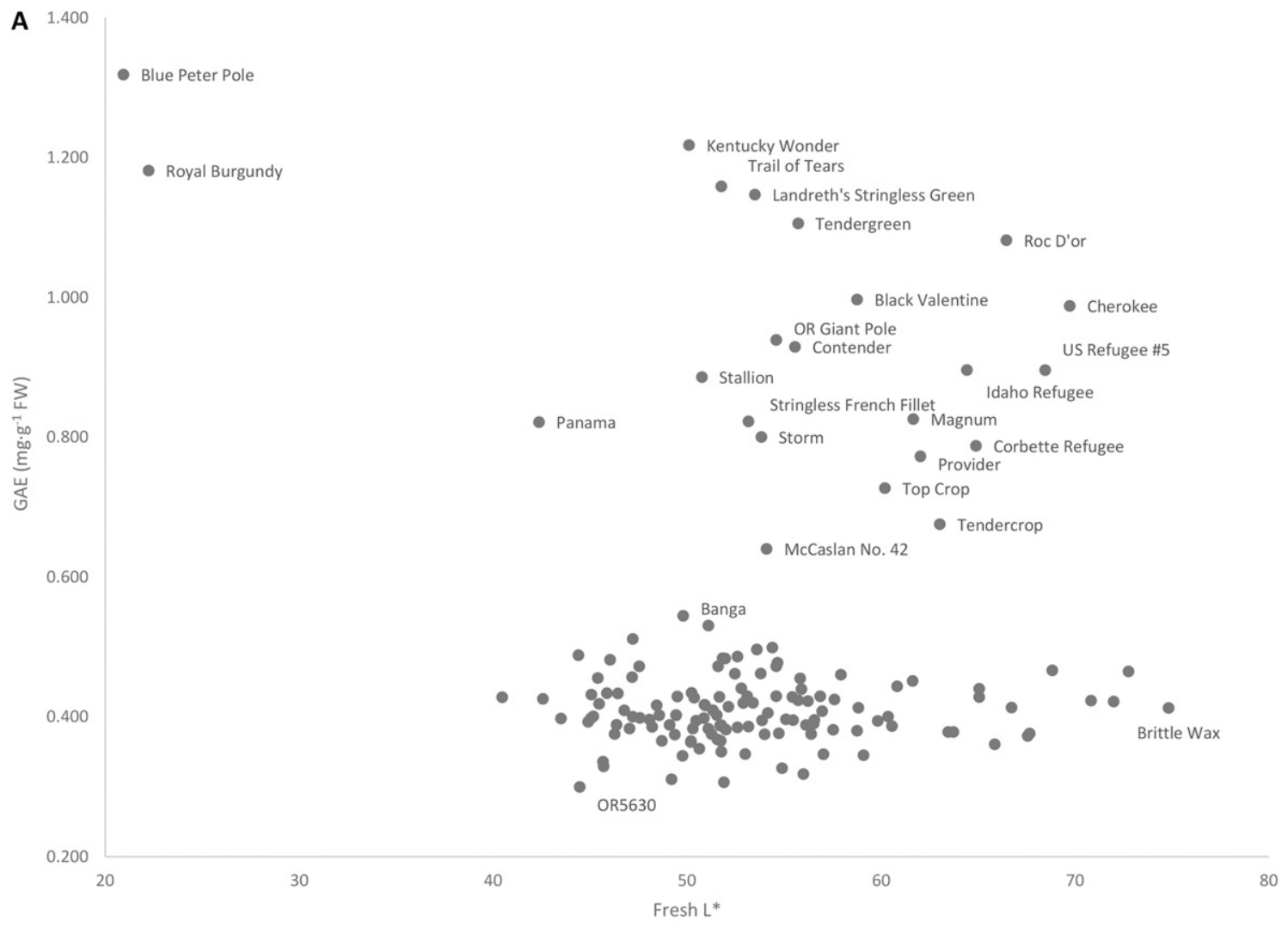

B
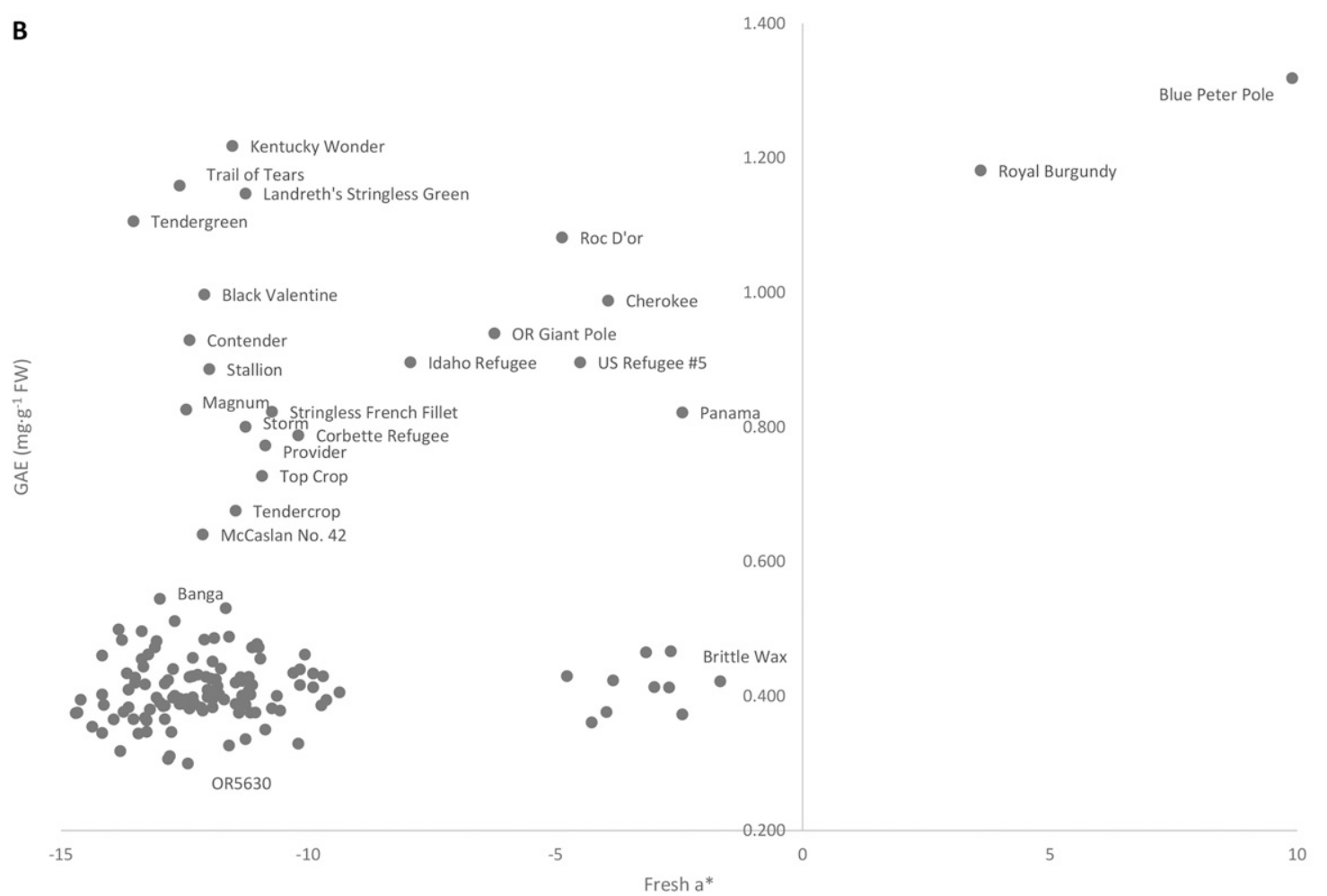

Fig. 1. Plots of total phenolic content (TCP) [milligrams gallic acid equivalent (GAE) per gram fresh weight] vs. CIE (Commission Internationale de L'Eclairage) $\mathrm{L}^{*} \mathrm{a} \mathrm{b}^{*}$ color scores for fresh snap bean pods of Bean Coordinated Agriculture Project Snap Bean Diversity Panel cultivars grown in a trial at the Oregon State University Vegetable Research Farm near Corvallis, OR in 2010. Cultivars in the high and intermediate TPC categories listed in Table 1 are labeled on the plots. For cultivars in the low TPC category, three representative ones are labeled (OR5630, Brittle Wax, and Banga). (A) TCP vs. L* [dark (0) vs. light (100)], (B) TCP vs. $a^{*}[$ red $(+)$ vs. green $(-)]$, and (C) TCP vs. b* [yellow (+) vs. blue (-)]. 


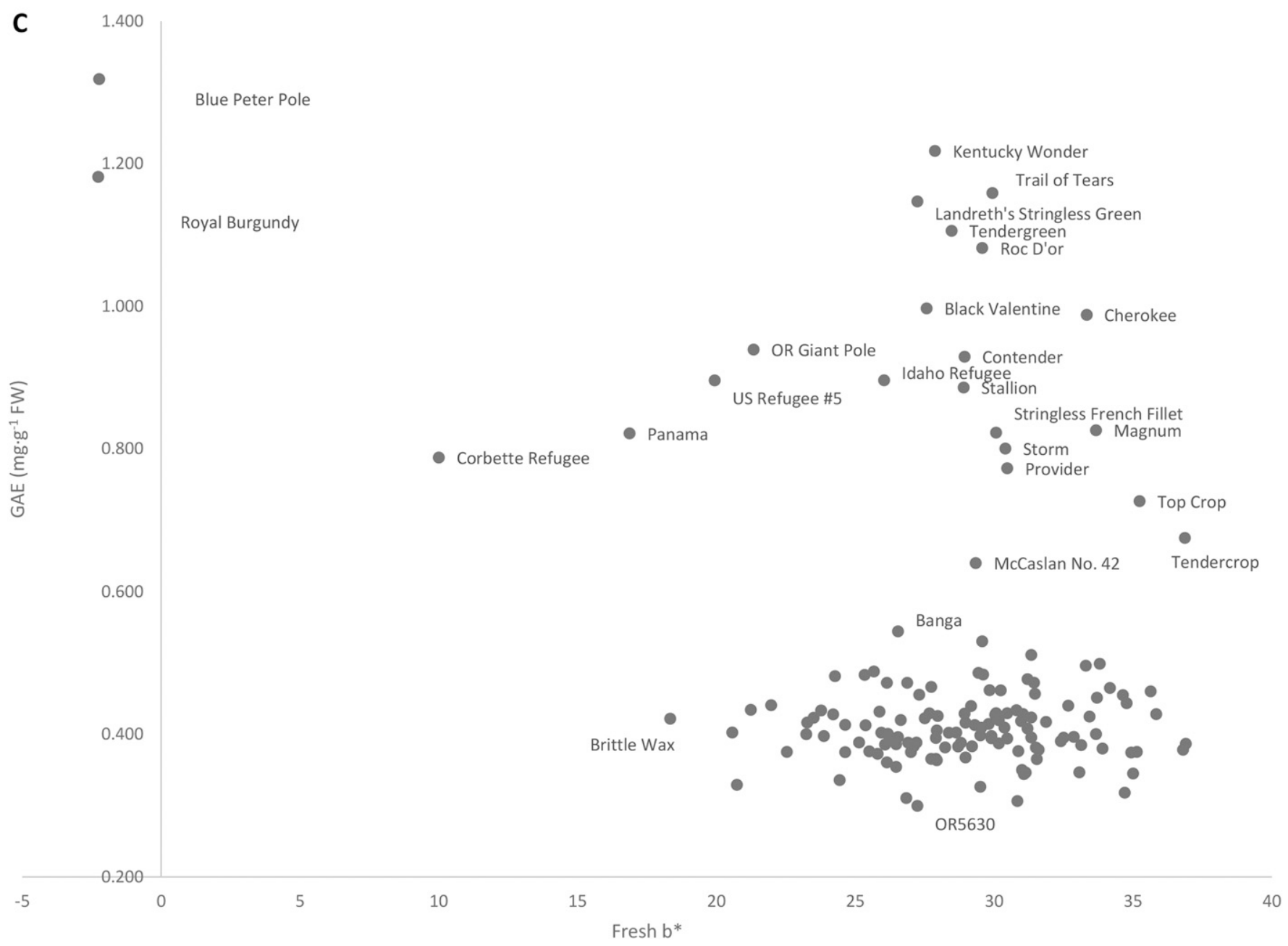

Fig. 1. (Continued)

Table 2. Pearson's correlation coefficients $(r)$ among total phenolic content (TPC) and fresh or frozen and thawed snap bean pod CIE (Commission Internationale de L'Eclairage) color of the Bean Coordinated Agriculture Project Snap Bean Diversity Panel.

\begin{tabular}{|c|c|c|c|c|c|c|}
\hline Trait & ТPC & Fresh pod L* & Fresh pod a* & Fresh pod b* & Frozen pod L* & Frozen pod a* \\
\hline Fresh pod L* & -0.04 & & & & & \\
\hline Fresh pod a* & $0.40 * * *$ & 0.10 & & & & \\
\hline Fresh pod b* & $-0.34 * * *$ & $0.44 * * *$ & $-0.63 * * *$ & & & \\
\hline Frozen pod L* & $0.20^{*}$ & $0.78 * * *$ & $0.59 * * *$ & 0.00 & & \\
\hline Frozen pod a* & 0.14 & $0.46 * * *$ & $0.74 * * *$ & $-0.27 * *$ & $0.67 * * *$ & \\
\hline Frozen pod b* & 0.12 & 0.14 & 0.02 & $-0.31 * *$ & 0.11 & 0.00 \\
\hline
\end{tabular}

*, **, ***Significant at $P \leq 0.05,0.01$, or 0.001 , respectively.

In general, cultivars that had $V$ or $v^{\text {lae }}$ had colored seed, but some cultivars classified as having white flowers $(v)$ also had colored seed (Table 1; Supplemental Table 1). All of the high TPC producing cultivars and most of those in the intermediate TPC category had colored seeds and all but one cultivar in the low TPC category had white or partially colored seed (Table 1). One cultivar (McCaslan No. 42) had white flowers and seeds and ranked at the bottom of the intermediate category. 'Brittle Wax', with white flowers but partially colored seed conditioned by $t$ had a low phenolic content (Table 1).

Information on approximate release dates of the 149 cultivars was also collected from multiple sources (Hendrick et al., 1931; USDA, 2015; Wehner, 2010; Whealy and Thuente, 2004). Although release information could not be determined for all of the cultivars, the high TPC category contained older cultivars, including some that were released before the 20th century. The intermediate TPC category tended to contain cultivars released from the early to mid-20th century, although exceptions existed such as the more recently released Royal Burgundy, Fortex, and Roc D'or in the high TPC category, and Magnum, Stallion, and Storm in the intermediate TPC category. On average, the low TPC category tended to be represented by cultivars released from the early 20th century to near present (Supplemental Table 1).

A subsample of both pole and bush cultivars were grown during 2010 and 2011 to estimate the $G \times E$ effects for TPC. There were no $\mathrm{G} \times \mathrm{E}$ interactions observed for the pole and halfrunner cultivars; however, a significant $\mathrm{G} \times \mathrm{E}$ interaction was observed for the bush cultivars (Table 4). The statistically significant interaction was apparently due to the response of 'Storm', which had a greater increase from one environment to the next compared with the other cultivars (Supplemental Table 2). 
Table 3. Least-square means for total phenolic content (TPC), and fresh and frozen CIE (Commission Internationale de L'Eclairage) $\mathrm{L}^{*} \mathrm{a} \mathrm{b}^{*}$ snap bean pod color scores across Bean Coordinated Agriculture Project Snap Bean Diversity Panel cultivars grouped by flower color classification.

\begin{tabular}{|c|c|c|c|c|c|c|c|c|c|c|}
\hline \multirow[b]{3}{*}{ Flower color ${ }^{z}$} & \multirow{2}{*}{\multicolumn{2}{|c|}{ ТPC }} & \multicolumn{8}{|c|}{ Pod color } \\
\hline & & & \multicolumn{4}{|c|}{ Fresh } & \multicolumn{4}{|c|}{ Frozen } \\
\hline & $\overline{N^{\mathrm{y}}}$ & {$\left[\mathrm{GAE}\left(\mathrm{mg} \cdot \mathrm{g}^{-1} \mathrm{FW}\right)\right]^{\mathrm{x}}$} & $N$ & $\mathrm{~L}^{*}$ & $a^{*}$ & $\mathrm{~b}^{*}$ & $N$ & $\mathrm{~L}^{*}$ & $a^{*}$ & $b^{*}$ \\
\hline$v$ & 132 & $0.44 \mathrm{~b}^{\mathrm{w}}$ & 131 & $53.4 \mathrm{~b}$ & $-11.5 b$ & $29.1 \mathrm{a}$ & 131 & $44.4 \mathrm{~b}$ & $-16.4 b$ & 31.3 \\
\hline$v^{l a e}$ & 5 & $0.99 \mathrm{a}$ & 5 & $60.9 \mathrm{a}$ & $-9.0 \mathrm{ab}$ & $28.1 \mathrm{a}$ & 5 & $50.6 \mathrm{a}$ & $-13.3 \mathrm{a}$ & 32.0 \\
\hline$V$ & 11 & $0.89 \mathrm{a}$ & 11 & $51.6 \mathrm{~b}$ & $-5.9 \mathrm{a}$ & $20.0 \mathrm{~b}$ & 10 & $49.1 \mathrm{a}$ & $-14.8 \mathrm{ab}$ & 31.4 \\
\hline
\end{tabular}

${ }^{z} v=$ white; $v^{\text {lae }}=$ lavender; $V=$ purple.

${ }^{y}$ Number of cultivars in each color class

${ }^{\mathrm{x}} \mathrm{GAE}=$ gallic acid equivalent.

wLeast square means followed by the same letter within a column are not significantly different at $P \leq 0.05$.

Table 4. Analysis of variance for pole and bush snap bean cultivar subsamples for total phenolic content from the Bean Coordinated Agriculture Project Snap Bean Diversity Panel grown during 2010 and 2011 .

\begin{tabular}{|c|c|c|c|c|c|c|}
\hline \multirow[b]{2}{*}{ Source } & \multicolumn{3}{|c|}{ Pole cultivars } & \multicolumn{3}{|c|}{ Bush cultivars } \\
\hline & df & Mean square & F value & df & Mean square & F value \\
\hline Year (Y) & 1 & 0.040 & 0.53 & 1 & 0.062 & $8.95^{*}$ \\
\hline Rep (Year) & 4 & 0.027 & 0.56 & 4 & 0.002 & 0.84 \\
\hline Cultivar (C) & 5 & 0.288 & 2.98 & 5 & 0.216 & $28.26 * *$ \\
\hline $\mathrm{C} \times \mathrm{Y}$ & 5 & 0.097 & 1.97 & 5 & 0.008 & $2.90 *$ \\
\hline Error & 20 & 0.049 & & 18 & 0.003 & \\
\hline
\end{tabular}

*, **Significant at $P \leq 0.05$ or 0.01 , respectively.

\section{Discussion}

This research represents the first report for the range of TPC occurring in a large and diverse collection of snap beans. These results suggest a strong association among TPC and some phenotypic traits and are consistent with other more limited studies, which used different extraction solvents and the FolinCiocalteu method. Baardseth et al. (2010) reported a range of 0.218 to $0.289 \mathrm{mg} \cdot \mathrm{g}^{-1} \mathrm{GAE}$ TPC in extracts from snap beans that underwent different cooking methods commonly used in the catering industry. Jiratanan and Liu (2004) also reported the TPC of extracts from snap beans that were exposed to different cooking temperatures and times and reported an approximate TPC of $0.8 \mathrm{mg} \cdot \mathrm{g}^{-1} \mathrm{GAE}$ in the control, which decreased with cooking. Selan et al. (2014) reported the TPC of four different snap bean cultivars, including Top Crop and Paulista, taking into account pod size and hail net cover, and reported a range of $\approx 0.13$ to $0.30 \mathrm{mg} \cdot \mathrm{g}^{-1} \mathrm{GAE}$, which was considerably lower than our findings for the same cultivars (Supplemental Table 1).

Currently, health problems and diet-related chronic diseases such as obesity, type 2 diabetes, cardiovascular disease, and cancer affect a large portion of the population both in the United States and globally. Therefore, the development of cultivars with higher phytochemical content that function in the prevention of chronic diseases is an important goal (Sands et al., 2009; Scalbert et al., 2005; Thompson and Thompson, 2009). The identification of snap bean cultivars with high levels of TPC may be useful for breeding cultivars with high antioxidant potential.

Different strategies to develop high TPC cultivars would have to be pursued for processed vs. fresh market green beans. Processors require that bean cultivars for canned products have white flowers and seed because the water-soluble anthocyanin compounds leach into the brine and cause discoloration, and in processed beans that are frozen, a cut bean seedcoat may appear as a purple ring in the pod and reduce the visual quality of the product (Myers and Baggett, 1999). Snap bean breeders rely on the recessive allele at the $P$ locus to produce whiteseeded phenotypes. Recessive $p$ interrupts the flavonoid pathway and greatly reduces these compounds (Bassett, 2007). In our material, cultivars with white seeds have low milligrams GAE per gram FW. The exception, and of considerable interest in breeding white seeded snap beans for higher levels of TPC, is 'McCaslan No. 42', a heirloom cultivar of unknown pedigree. This cultivar is a fresh market pole bean, requiring a significant breeding effort to transfer the white seed phenotype into a contemporary bush background while selecting for high TPC. It should be noted that several different multigenic combinations in addition to $p$ can condition white seed color in common bean and it is possible that 'McCaslan No. 42' has one or more factors different from $p$ that may produce a white seedcoat but still allow some expression of TPC.

Since green beans are grown for home garden and fresh market, there is greater choice in cultivars with colored flowers and seed. There is less concern about the presence of watersoluble pigments in the immature seeds and pods. In addition, cultivars with colored seeds show greater resistance to soilborne pathogens (Hagerty et al., 2015) and this may account for the persistence in retail seed catalogs of certain heirloom cultivars such as: Contender, Provider, and Top Crop. The lower levels in TPC observed in newer cultivars is likely the result of breeders developing only white-seeded cultivars. Unfortunately, the recent trend has been for snap bean breeders to breed for the processing markets and ignore the potential for fresh market beans that have high concentrations of flavonoids.

The results suggest an association between CIE $\mathrm{a}^{*}$ and $\mathrm{b}^{*}$ scores for fresh pod color and TPC. The CIE a* was positively correlated, and $b^{*}$ was negatively correlated with TPC. The association between $\mathrm{a}^{*}$ and TPC was produced by a shift from green to red associated with higher TPC, although the negative correlation between $b^{*}$ and TPC indicated a shift from yellow toward blue. Fresh and frozen CIE L* and $\mathrm{a}^{*}$ showed positive correlations of $r=0.74-0.78$, whereas $b^{*}$ had a relatively low $(r=-0.31)$ correlation between fresh and frozen samples (Table 2). Since phenolics and flavonoids are water soluble, it is apparent from these data that the freezing process modifies pod color, and it is likely that leakage of phenolics and other flavonoids occurs after thawing. It appears that selection for increased TPC could be practiced using a combination of CIE $a^{*}$ and $b^{*}$ on fresh pods.

The pole cultivars had significantly higher TPC as compared with the bush-type cultivars. However, the bush-type cultivars are the predominant type that is grown commercially. This occurred because pole beans represent ancestral types from which bush cultivars were developed with the intent of reducing labor costs by breeding for mechanical harvest. Pole and halfrunner bean cultivars tend to be older and also tend to have 
colored flowers and seeds. Thus, the association between pole growth habit and TPC is likely the result of historical association with colored flowers and seeds.

The low TPC of 'Brittle Wax' that has colored seeds is most likely due to the recessive $t$ allele, which reduces the area of color expression in the testa by $80 \%$ or more in this cultivar and conditions the white flower color in the presence of the dominant $V$ allele (Bassett and McClean, 2000). It was not previously known how allele $t$ affects expression in stems, leaves, and pods, but it appears to have a pleiotropic effect in reducing TPC in pods, which has not been previously reported.

In summary, a 4.4-fold range of variation for TPC was observed in the Bean CAP panel of 149 snap bean cultivars. A preliminary assessment of a subsample of pole and bush cultivars over two production years indicates that the TPC trait does not appear to be strongly influenced by $\mathrm{G} \times \mathrm{E}$ effects and that breeding for improved levels of TPC will result in higher TPC across a range of environments. We reach this conclusion because $\mathrm{G} \times \mathrm{E}$ interaction was only observed in the bush category with one cultivar in particular contributing to the interaction (Supplemental Table 2). However, further evaluation of a larger number of cultivars over additional environments would be needed to further verify the effects of cultivar, environment, and $\mathrm{G} \times \mathrm{E}$ for TPC in snap beans. In addition, the identification of correlated phenotypic traits associated with TPC will also be useful to snap bean breeders. The TPC represents only one phytochemical class and does not reflect the overall nutritional composition of the cultivars. However, the results illustrate the degree of variation that exists across snap bean cultivars for TPC and the likelihood of breeding for improved TPC.

\section{Literature Cited}

Abu-Reidah, I.M., D. Arráez-Román, J. Lozano-Sánchez, A. SeguraCarretero, and A. Fernández-Gutiérrez. 2013. Phytochemical characterisation of green beans (Phaseolus vulgaris L.) by using highperformance liquid chromatography coupled with time-of-flight mass spectrometry. Phytochem. Anal. 24:105-116.

Amarowicz, R. and R.B. Pegg. 2008. Legumes as a source of natural antioxidants. Eur. J. Lipid Sci. Technol. 110:865-878.

Baardseth, P., F. Bjerke, B.K. Martinsen, and G. Skrede. 2010. Vitamin C, total phenolics, and antioxidative activity in tip-cut green beans (Phaseolus vulgaris) and swede rods (Brassica napus var. napobrassica) processed by methods used in catering. J. Sci. Food Agr. 90:1245-1255.

Bassett, M.J. 2007. Genetics of seed coat color and pattern in common bean. Plant Breeding Rev. 28:239-315.

Bassett, M.J. and P.E. McClean. 2000. A brief review of the genetics of partly colored seed coats in common bean. Annu. Rep. Bean Improv. Coop. 43:99-101.

Bazzano, L.A., J. He, L.G. Ogden, C. Loria, S. Vupputuri, L. Myers, and P.K. Whelton. 2001. Legume consumption and risk of coronary heart disease in US men and women: NHANES I epidemiologic follow-up study. Arch. Intern. Med. 161:2573-2578.

Blair, M.W., A. Chaves, A. Tofino, J.F. Calderon, and J.D. Palacio. 2010. Extensive diversity and inter-genepool introgression in a world-wide collection of indeterminate snap bean accessions. Theor. Appl. Genet. 120:1381-1391.

Câmara, C., C. Urrea, and V. Schlegel. 2013. Pinto beans (Phaseolus vulgaris L.) as a functional food: Implications on human health. Agriculture 3:90-111.

Commission Internationale de L'Eclairage. 2008. CIE colorimetryPart 4: 1976 L*a*b* Colour Space. ISO 11664-4:2008(E)/CIE S 0144/E:2007. 1 Dec. 2008. <http://cie.co.at/index.php?i_ca_id=485>.
Crozier, A., I.B. Jaganath, and M.N. Clifford. 2009. Dietary phenolics: Chemistry, bioavailability and effects on health. Nat. Prod. Rpt. 26:1001-1043.

Escarpa, A. and M.C. Gonzalez. 2000. Identification and quantitation of phenolics from green beans by high-performance liquid chromatography. Chromatographia 52:33-38.

Hagerty, C.H., A. Cuesta-Marcos, P.B. Cregan, Q. Song, P. McClean, S. Noffsinger, and J.R. Myers. 2015. Mapping and root rot resistance and root architecture quantitative trait loci in common bean. Crop Sci. 55:1969-1977.

Hempel, J. and H. Böhm. 1996. Quality and quantity of prevailing flavonoid glycosides of yellow and green french beans (Phaseolus vulgaris L.). J. Agr. Food Chem. 44:2114-2116.

Hendrick, U.P., W.T. Tapley, G.P. Van Eseltine, and W.D. Enzie. 1931. The vegetables of New York: Beans of New York. New York Agr. Expt. Sta., J.B. Lyon Co., Albany, NY.

Hertog, M.G.L., P.C.H. Hollman, and M.B. Katan. 1992. Content of potentially anticarcinogenic flavonoids of 28 vegetables and 9 fruits commonly consumed in the Netherlands. J. Agr. Food Chem. 40:2379-2383.

Hounsome, N., B. Hounsome, D. Tomos, and G. Edwards-Jones. 2008. Plant metabolites and nutritional quality of vegetables. J. Food Sci. 73:R48-R65.

Jiratanan, T. and R.H. Liu. 2004. Antioxidant activity of processed table beets (Beta vulgaris var. conditiva) and green beans (Phaseolus vulgaris L.). J. Agr. Food Chem. 52:2659-2670.

Mattila, P. and J. Hellström. 2007. Phenolic acids in potatoes, vegetables, and some of their products. J. Food Compos. Anal. 20:152-160.

McClean, P.E., R.K. Lee, C. Otto, P. Gepts, and M.J. Bassett. 2002. Molecular and phenotypic mapping of genes controlling seed coat pattern and color in common bean (Phaseolus vulgaris L.). J. Hered. 93:148-152.

Myers, J. and J. Baggett. 1999. Improvement of snap bean, p. 289-329. In: S. Singh (ed.). Common bean improvement in the twenty-first century. Springer, Dordrecht, The Netherlands.

Pari, L. and S. Venkateswaran. 2003. Effect of an aqueous extract of Phaseolus vulgaris on the properties of tail tendon collagen of rats with streptozotocin-induced diabetes. Braz. J. Med. Biol. Res. 36:861-870.

Parr, A.J. and G.P. Bolwell. 2000. Phenols in the plant and in man. The potential for possible nutritional enhancement of the diet by modifying the phenols content or profile. J. Sci. Food Agr. 80:985-1012.

Prakken, R. 1934. Inheritance of colours and pod characters in Phaseolus vulgaris L. Genetica 16:177-296.

Prakken, R. 1940. Inheritance of colors in Phaseolus vulgaris L. Genetica 22:331-408.

Prakken, R. 1970. Inheritance of colour in Phaseolus vulgaris L. II: A critical review. Mededeelingen Landbouwhogeschool Wageningen 70(Pt 23):1-38.

Prakken, R. 1972a. Seedcoat colour in Phaseolus vulgaris L. attempt to a general synthesis. Annu. Rep. Bean Improv. Coop. 15:74-79.

Prakken, R. 1972b. Inheritance of colours in Phaseolus vulgaris L. III: On genes for red seed coat colour and a general synthesis. Mededeelingen Landbouwhogeschool Wageningen 72(Pt 29):1-82. Prakken, R. 1974. Inheritance of colours in Phaseolus vulgaris L. IV: Recombination within the "complex locus C". Mededeelingen Landbouwhogeschool Wageningen 74(Pt 24):1-36.

Reinprecht, Y., Z. Yadegari, G.E. Perry, M. Siddiqua, L.C. Wright, P.E. McClean, and P.K. Pauls. 2013. In silico comparison of genomic regions containing genes coding for enzymes and transcription factors for the phenylpropanoid pathway in Phaseolus vulgaris L. and Glycine max L. Merr. Front. Plant Sci. 4:1-25.

Roman-Ramos, R., J.L. Flores-Saenz, and F.J. Alarcon-Aguilar. 1995. Anti-hyperglycemic effect of some edible plants. J. Ethnopharmacol. 48:25-32.

Sands, D.C., C.E. Morris, E.A. Dratz, and A.L. Pilgeram. 2009. Elevating optimal human nutrition to a central goal of plant breeding and production of plant-based foods. Plant Sci. 177:377-389. 
Scalbert, A., C. Manach, C. Morand, C. Rémésy, and L. Jiménez. 2005. Dietary polyphenols and the prevention of diseases. Crit. Rev. Food Sci. Nutr. 45:287-306.

Selan, M., D. Kastelec, J. Jakopič, R. Veberič, M. Mikulič-Petkovšek, and N. Kacjan-Maršić. 2014. Hail net cover, cultivar, and pod size influence the chemical composition of dwarf french bean. Sci. Hort. 175:95-104.

Singleton, V.L. and J.A. Rossi. 1965. Colorimetry of total phenolics with phosphomolybdic-phosphotungstic acid reagents. Amer. J. Enol. Viticult. 16:144-158.

Thompson, M.D., M.A. Brick, J.N. McGinley, and H.J. Thompson. 2009. Chemical composition and mammary cancer inhibitory activity of dry bean. Crop Sci. 49:179-186.

Thompson, M.D. and H.J. Thompson. 2009. Biomedical agriculture: A systematic approach to food crop improvement for chronic disease prevention. Adv. Agron. 102:1-54.
U.S. Department of Agriculture. 2014. Food Availability (Per Capita) Data System. 4 Dec. 2014. <http://www.ers.usda.gov/datafiles/ Food_Availabily_Per_Capita_Data_System/Food_Availability/ vegtot.xls>.

U.S. Department of Agriculture. 2015. Plant Variety Protection Office List of U.S. Protected Varieties, Garden Bean. 14 Aug. 2015. <http:// www.ars-grin.gov/cgi-bin/npgs/html/pvp.pl?Bean,\%20garden>.

Wehner, T.C. 2010. Vegetable Cultivar Descriptors for North America. 20 June 2010. <http://cuke.hort.ncsu.edu/cucurbit/wehner/ vegcult/vgclintro.html>.

Whealy, K. and J. Thuente. 2004. Garden seed inventory: An inventory of seed catalogs listing all non-hybrid vegetable seeds available in the United States and Canada. Seed Savers Exchange, Decorah, IA. Xu, B.J. and S.K.C. Chang. 2007. A comparative study on phenolic profiles and antioxidant activities of legumes as affected by extraction solvents. J. Food Sci. 72:S159-S166. 


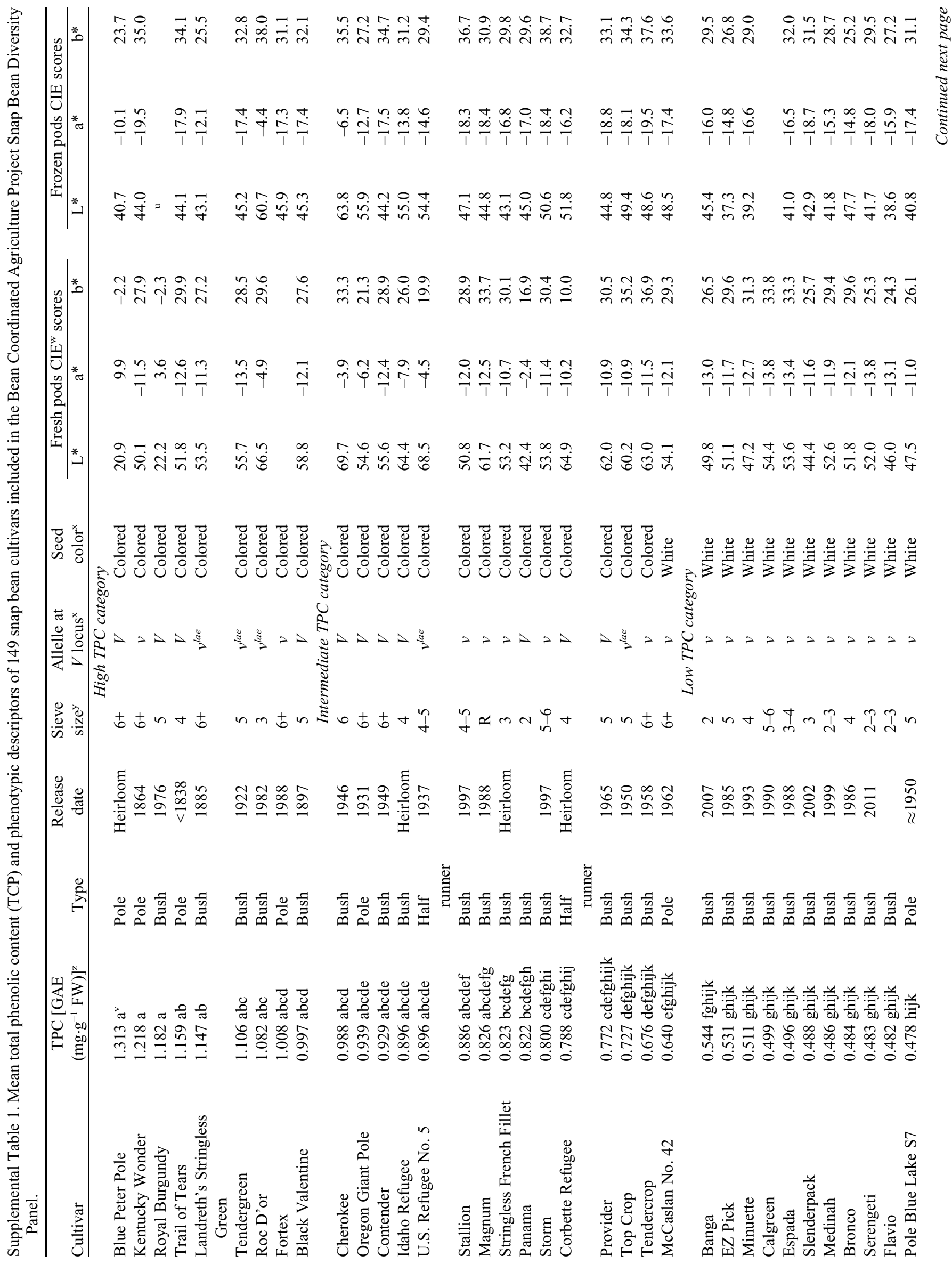


ト

*

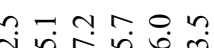

ภำ

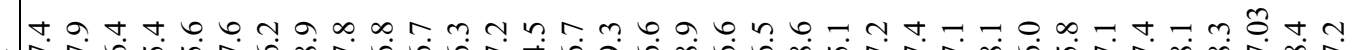

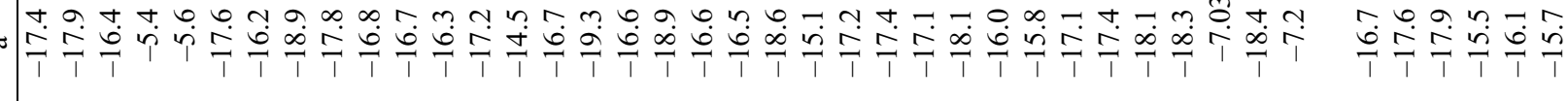

r-t

o.

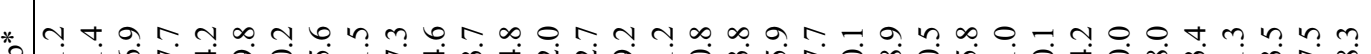

m

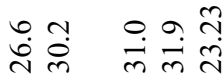

*

은

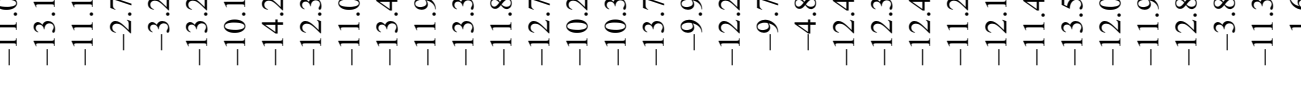

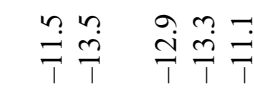

承

* $\neg 0$.

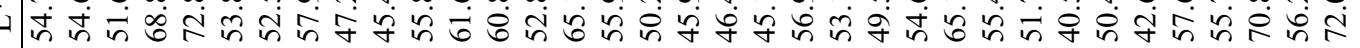

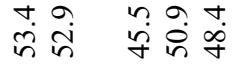

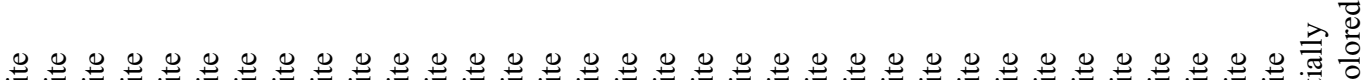

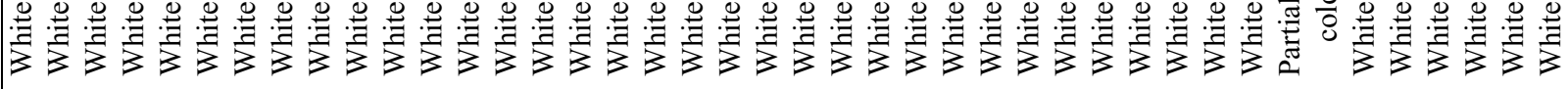

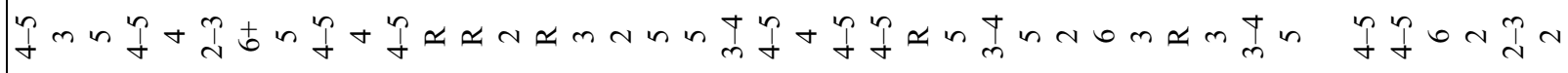

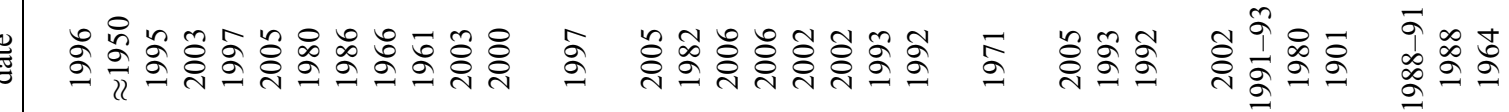

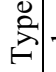

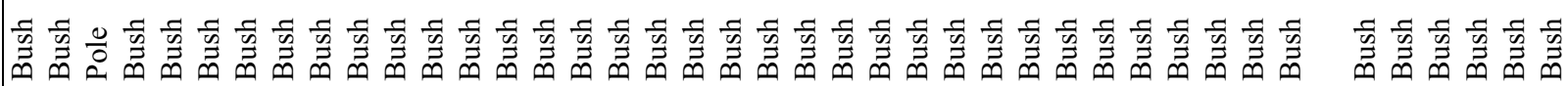

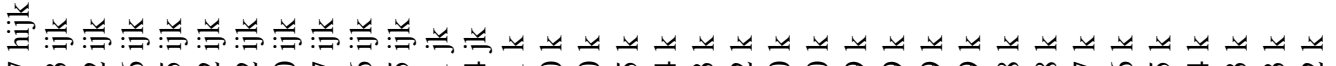

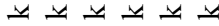

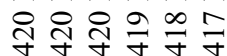

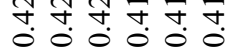

农

\section{(1)}

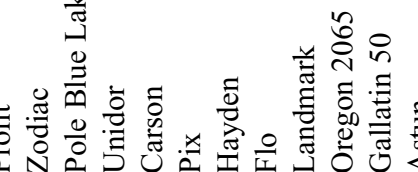


ด m $\infty$ o m

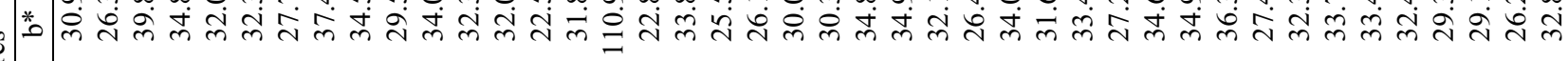

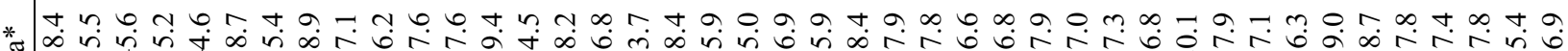
各

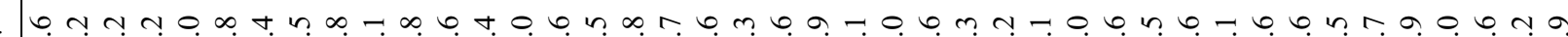
* |

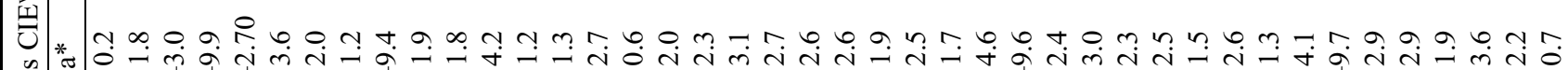
学 总

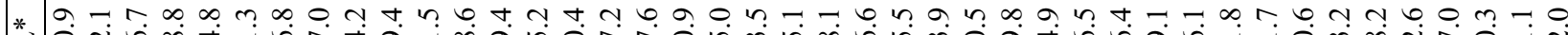

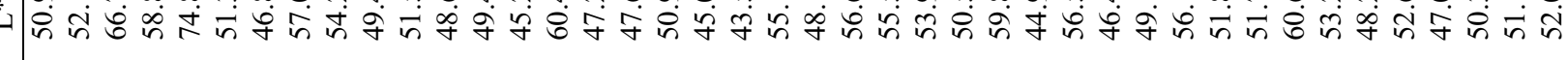

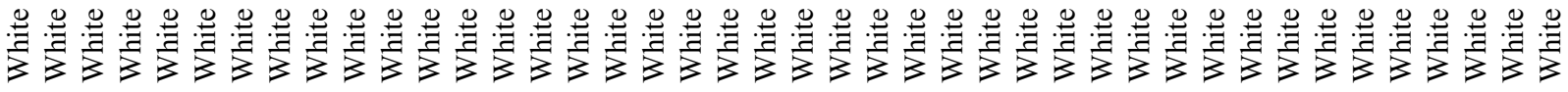
等

要 西 \&

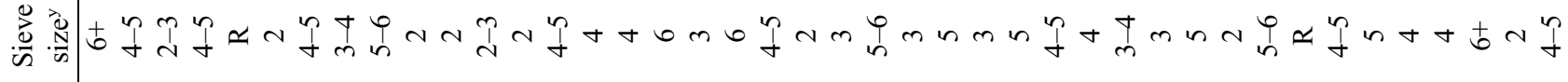
㟧

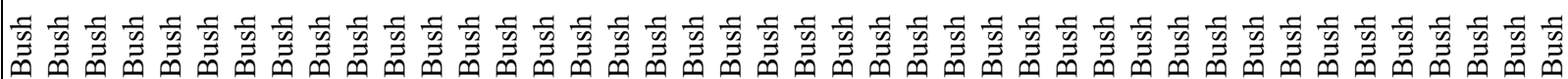

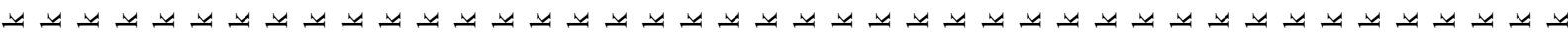

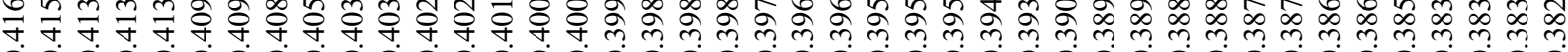

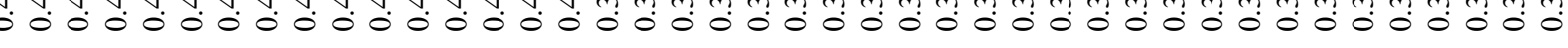




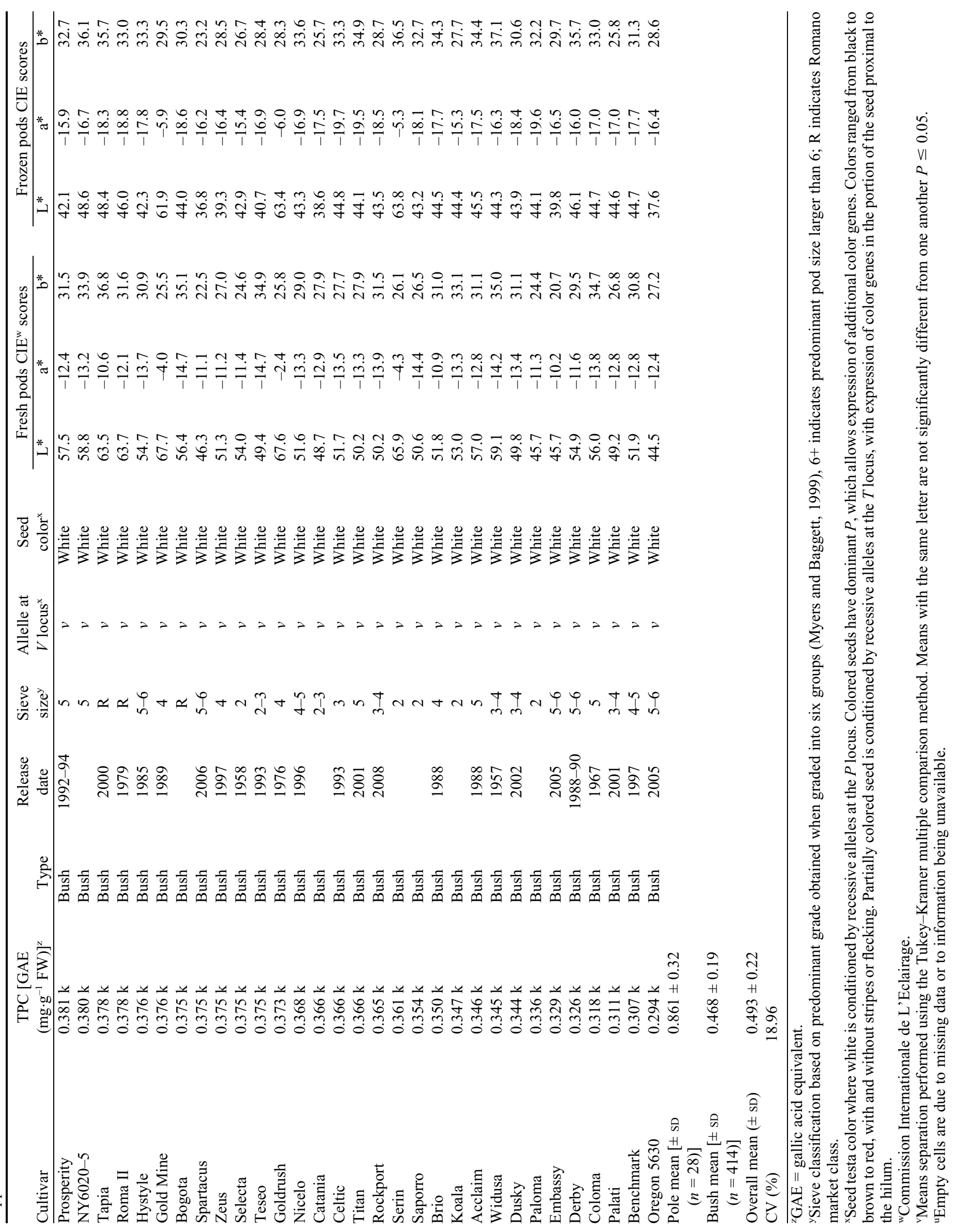


Supplemental Table 2. Genotype $\times$ environment interaction for total phenolic content (TPC) in subsample from the Bean Coordinated Agriculture Project Snap Bean Diversity Panel of bush and pole snap bean cultivars grown in 2010 and 2011. Cultivars in different growth habit groups were analyzed separately.

\begin{tabular}{|c|c|c|c|c|c|}
\hline \multirow[b]{3}{*}{ Cultivar } & \multicolumn{4}{|c|}{$\mathrm{Yr}$} & \multirow[b]{3}{*}{$P$ value } \\
\hline & \multicolumn{2}{|r|}{2010} & \multicolumn{2}{|r|}{2011} & \\
\hline & $\begin{array}{l}\text { Reps } \\
\text { (no.) }\end{array}$ & $\begin{array}{c}\text { TPC }\{\text { mean } \pm \text { SD } \\
\left.\left[\mathrm{GAE}\left(\mathrm{mg} \cdot \mathrm{g}^{-1} \mathrm{FW}\right)\right]\right\}^{\mathrm{z}}\end{array}$ & $\begin{array}{l}\text { Reps } \\
\text { (no.) }\end{array}$ & $\begin{array}{c}\text { TPC }\{\text { mean } \pm \text { SD } \\
\left.\left[\mathrm{GAE}\left(\mathrm{mg} \cdot \mathrm{g}^{-1} \mathrm{FW}\right)\right]\right\}\end{array}$ & \\
\hline \multicolumn{6}{|c|}{ Pole } \\
\hline Corbette Refugee & 3 & $0.79 \pm 0.26$ & 3 & $1.11 \pm 0.12$ & 0.7865 \\
\hline Fortex & 3 & $1.01 \pm 0.13$ & 3 & $1.22 \pm 0.15$ & 0.9846 \\
\hline Kentucky Wonder & 3 & $1.22 \pm 0.20$ & 3 & $0.96 \pm 0.29$ & 0.9452 \\
\hline McCaslan No. 42 & 3 & $0.64 \pm 0.16$ & 3 & $0.71 \pm 0.28$ & 1.0000 \\
\hline Pole Blue Lake & 3 & $0.47 \pm 0.04$ & 3 & $0.75 \pm 0.26$ & 0.9139 \\
\hline Trail of Tears & 3 & $1.16 \pm 0.28$ & 3 & $0.93 \pm 0.23$ & 0.9947 \\
\hline Overall year mean & & $0.88 \pm 0.32$ & & $0.95 \pm 0.27$ & 0.3728 \\
\hline \multicolumn{6}{|c|}{ Bush } \\
\hline Banga & 3 & $0.54 \pm 0.07$ & 3 & $0.59 \pm 0.02$ & 0.9919 \\
\hline Ebro & 3 & $0.44 \pm 0.11$ & 3 & $0.47 \pm 0.03$ & 1.0000 \\
\hline Goldmine & 3 & $0.38 \pm 0.01$ & 3 & $0.43 \pm 0.02$ & 0.9800 \\
\hline Impact & 3 & $0.42 \pm 0.00$ & 3 & $0.50 \pm 0.05$ & 0.7342 \\
\hline OR5630 & 1 & 0.30 & 3 & $0.45 \pm 0.01$ & 0.4429 \\
\hline Storm & 3 & $0.80 \pm 0.08$ & 3 & $1.02 \pm 0.04$ & 0.0015 \\
\hline Overall year mean & & $0.50 \pm 0.17$ & & $0.58 \pm 0.21$ & $<0.0001$ \\
\hline
\end{tabular}

$\overline{{ }^{\mathrm{z}} \mathrm{GAE}}=$ gallic acid equivalent; $\mathrm{FW}=$ fresh weight. 